\title{
SITE SUITABILITY EVALUATION FOR ECOTOURISM DEVELOPMENT: A CASE STUDY IN BULUE VILLAGE, SOPPENG DISTRICT, INDONESIA
}

\author{
EKO YUWONO*1, RISMA ILLA MAULANY² AND ROLAND A. BARKEY² \\ ${ }^{1}$ Postgraduate School of Regional Planning, Hasanuddin University. ${ }^{2}$ Forestry Science, Hasanuddin University, Makassar, \\ 90245, Indonesia.
}

*Corresponding author: yuwono.wono@gmail.com

Submitted final draft: 18 May $2020 \quad$ Accepted: 3 June $2020 \quad$ http://doi.org/10.46754/jssm.2021.01.012

\begin{abstract}
This paper presents a case study of the landscape of Bulue Village in Soppeng District, Indonesia, showing that site suitability evaluation was an important step in the process of ecotourism development planning of protected area which accommodated the landscape characteristics. Spatial multicriteria decision analysis combined with descriptive analysis was utilized as a methodology in this study. The results of the analysis showed that the landscape had (1) highly suitable $1.33 \%$; (2) moderately suitable $16.94 \%$; (3) marginally suitable $73.21 \%$, and (4) not suitable $8.51 \%$ for ecotourism. Moreover, there were livelihood-based and nature-based tourism attraction potential and tourism market opportunities. However, there were the resistance factors that need to be overcome, particularly in preventing further forest degradation, improving access to tourism attractions, and empowering the community. This paper points out the importance of evaluating and mapping of landscape characteristics in the process of ecotourism development planning of Bulue Village to ensure sustainable use of landscape.
\end{abstract}

Keywords: Ecotourism development planning, landscape characteristics, protected area, bulue village.

\section{Introduction}

Sustainable tourism is a level of tourism activity that can be maintained over the long term because it results in a net benefit for the social, economic, environmental, and cultural (Stoddard et al., 2012). Ecotourism is a component of sustainable tourism (Bunruamkaew \& Murayama, 2011; Kiper, 2013). According to The International Ecotourism Society, ecotourism as responsible travel to natural areas maintains the welfare of the local community and involves interpretation and education (Ecotourism.org, 2019). The development of ecotourism has to contribute minimal impact on ecosystems and to the local community's economy, as well as respect for the local culture. Ecotourism is developed using a participatory process that involves all stakeholders and is monitored to detect negative and positive impacts generated from the activities. Therefore, it becomes more common that ecotourism is seen as part of a protected area's management strategy. The integration of ecotourism with protected areas creates a symbiotic relationship: ecotourism needs protected areas and protected areas need ecotourism (Drumm \& Moore, 2005).

To develop ecotourism, site suitability can be evaluated through direct observation in the field (Sadikin et al., 2017), using Geographic Information System (Rahayuningsih et al., 2016) and integrating Geographic Information System and Analytical Hierarchy Process (Bunruamkaew \& Murayama, 2011; Liaghat et al., 2013; Dhami et al., 2014; Mobaraki et al., ; Mohd \& Ujang, 2016; Fernando \& Shariff, 2017). Most research have proved that GISbased AHP as a multi-criteria evaluation is a strong and effective way for tourism planning and so is helping in the effective development of ecotourism (Bunruamkaew \& Murayama, 2011; Mohd \& Ujang, 2016).

A landscape that functions as a protected area has a higher vulnerability value than other forms of the area. Landscape utilisation activities that ignore the value of vulnerability can harm environmental (water, soil, air, flora, and fauna) and cultural aspects (decreasing local wisdom values), and the beauty of the 
landscape. According to Janic and Sestras (2019), landscape inventory and evaluation concerning natural and spatial culture values are recognized as an important step in the process of landscape planning. Evaluation and mapping of landscape characteristics are commonly done by studies based on factors such as naturalness, diversity of habitat, and culture. While a landscape approach is an approach that accommodates conflicting interests related to land use, i.e. extractive economic functions and conservative environmental service functions (Prasetyo, 2017).

Bulue Village has various types of landscapes with hilly topography and different altitudes from 80 to $920 \mathrm{~m}$ above sea level (Statistics of Soppeng Regency, 2018). As indicated in the map (Figure 1), nearly $85 \%$ of the village's area is included as the conservation area (Lejja Recreation Park) and protected forest (Walanae Protected Forest). Only 15\% of the area is utilised as cultivated areas. Furthermore, Bulue landscape is a catchment area of the BatuBatu River which flows into lake Tempe. There are several settlements in Bulue Village. Most of the people have lived as farmers so that the potential of forest degradation and land tenure conflicts are very large in the area and tend to increase with the growing population (Forestry Agency of South Sulawesi Province, 2018).

Forest areas that are relatively critical due to forest degradation can reduce the value of the landscape so that forest management systems that are related to ecotourism are needed to create alternative income for the community. Thus, the purpose of this study is to evaluate site suitability for ecotourism development of Bulue Village.

\section{Materials and Methods}

To evaluate site suitability for ecotourism, the approaches used were the modified method of Bunruamkaew \& Murayama (2011) combined with Janic \& Sestras (2019). The descriptive analysis was also employed to describe the characteristics of the landscape. Meanwhile, the stages of this study were presented in Figure 2, which included preliminary studies, data collection, analysis, synthesis, and recommendation.

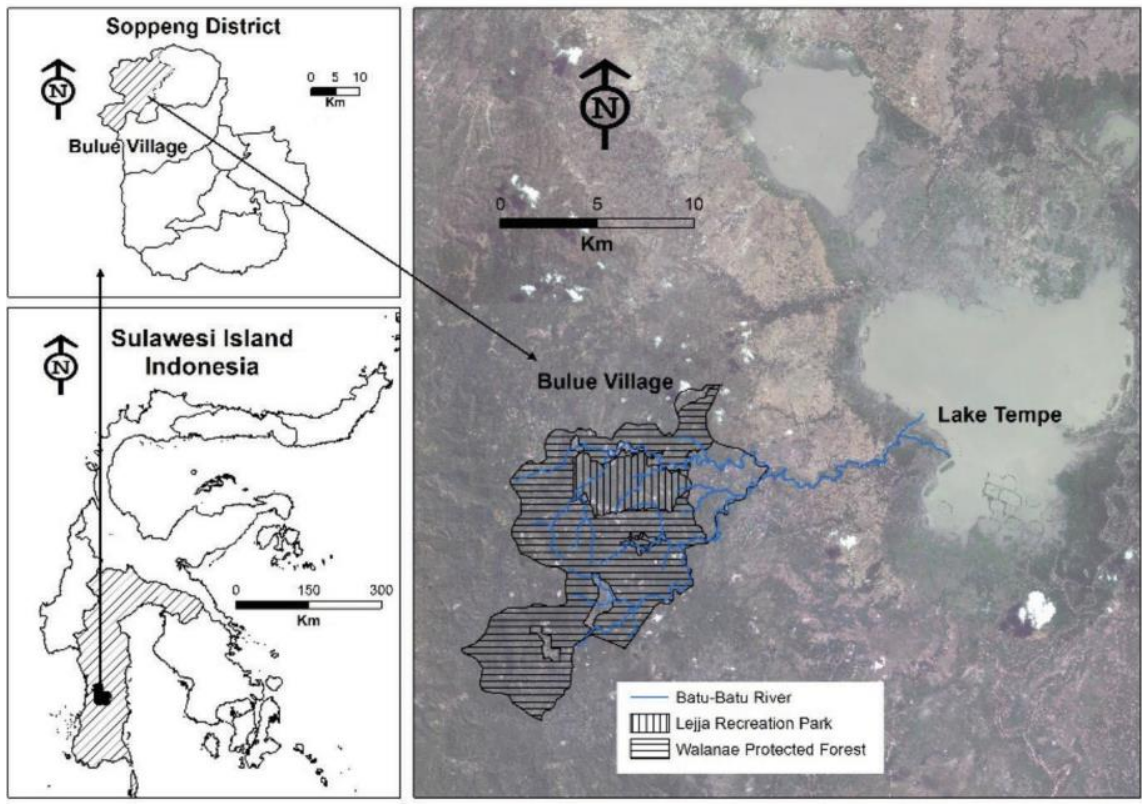

Figure 1. The geographical location of Bulue Village, Soppeng District, Indonesia

Source: Ministry of Environment \& Forestry and Public Work and Housing Agency, Soppeng District,

Indonesia 


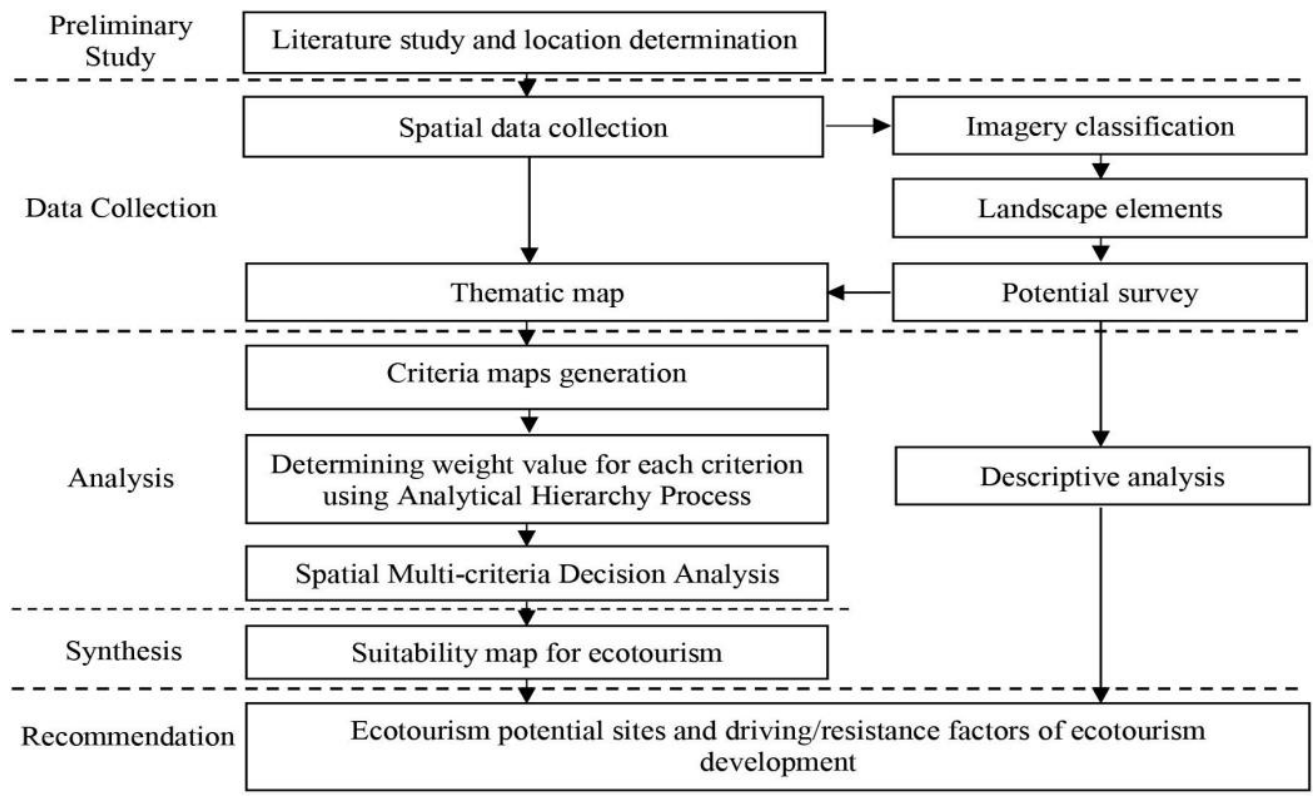

Figure 2: Phases of Study Process

Source: Bunruamkaew \& Murayama (2011) and Janic \& Sestras (2019), modified

\section{Preliminary Study}

In the preliminary study, spatial criteria and their evaluation scale for ecotourism site suitability evaluation (Table 1) were determined. This study was conducted by collecting, studying, and reviewing research articles related to the use of GIS and AHP in assessing the suitability of the site for ecotourism.

Table 1: Spatial criteria and their evaluation scale for ecotourism site suitability evaluation

\begin{tabular}{|c|c|c|c|c|}
\hline Criteria & Sub criteria & Range & $\begin{array}{c}\text { Evaluation } \\
\text { Scale }\end{array}$ & Score \\
\hline \multirow{4}{*}{ Slope } & \multirow{4}{*}{-} & $0-5^{\circ}$ & High & 4 \\
\hline & & $5-25^{\circ}$ & Moderate & 3 \\
\hline & & $25-35^{\circ}$ & Marginal & 2 \\
\hline & & $>35^{\circ}$ & Not suitable & 1 \\
\hline \multirow{8}{*}{ Accessibility } & \multirow{4}{*}{$\begin{array}{l}\text { Proximity from } \\
\text { existing touris m } \\
\text { destination sites }\end{array}$} & $0-1 \mathrm{~km}$ & High & 4 \\
\hline & & $1-2 \mathrm{~km}$ & Moderate & 3 \\
\hline & & $2-3 \mathrm{~km}$ & Marginal & 2 \\
\hline & & $>3 \mathrm{~km}$ & Not suitable & 1 \\
\hline & \multirow[t]{4}{*}{$\begin{array}{l}\text { Distance from } \\
\text { roads }\end{array}$} & $\begin{array}{l}0-200 \mathrm{~m} \text { from the main road } \\
0-100 \mathrm{~m} \text { from the secondary road } \\
0-50 \mathrm{~m} \text { from trail road }\end{array}$ & High & 4 \\
\hline & & $\begin{array}{l}200-400 \mathrm{~m} \text { from the main road } \\
100-200 \mathrm{~m} \text { from the secondary road } \\
50-100 \mathrm{~m} \text { from trail road }\end{array}$ & Moderate & 3 \\
\hline & & $\begin{array}{l}400-600 \mathrm{~m} \text { from the main road } \\
200-300 \mathrm{~m} \text { from the secondary road } \\
100-150 \mathrm{~m} \text { from trail road }\end{array}$ & Marginal & 2 \\
\hline & & $\begin{array}{l}>600 \mathrm{~m} \text { from the main road } \\
>300 \mathrm{~m} \text { from the secondary road } \\
>150 \mathrm{~m} \text { from trail road }\end{array}$ & Not suitable & 1 \\
\hline
\end{tabular}




\begin{tabular}{|c|c|c|c|c|}
\hline \multirow{12}{*}{ Naturalness } & \multirow{4}{*}{ Land cover } & Primary forest & High & 4 \\
\hline & & Secondary forest & Moderate & 3 \\
\hline & & $\begin{array}{l}\text { Rainfed field, Rice field, Mixed plantation, } \\
\text { Swamp, Shrub }\end{array}$ & Marginal & 2 \\
\hline & & Settlement & Not suitable & 1 \\
\hline & \multirow{4}{*}{$\begin{array}{l}\text { Distance from } \\
\text { settlements }\end{array}$} & $>3 \mathrm{~km}$ & High & 4 \\
\hline & & $2-3 \mathrm{~km}$ & Moderate & 3 \\
\hline & & $1-2 \mathrm{~km}$ & Marginal & 2 \\
\hline & & $0-1 \mathrm{~km}$ & Not suitable & 1 \\
\hline & \multirow{4}{*}{$\begin{array}{l}\text { Preservation } \\
\text { status }\end{array}$} & Conservation forest; Protected forest & High & 4 \\
\hline & & Restricted production forest & Moderate & 3 \\
\hline & & Production forest & Marginal & 2 \\
\hline & & Other areas of use & Not suitable & 1 \\
\hline \multirow{4}{*}{$\begin{array}{l}\text { Water } \\
\text { resources }\end{array}$} & \multirow{4}{*}{-} & Distance from water resources $0-250 \mathrm{~m}$ & High & 4 \\
\hline & & Distance from water resources $250-500 \mathrm{~m}$ & Moderate & 3 \\
\hline & & Distance from water resources $500-750 \mathrm{~m}$ & Marginal & 2 \\
\hline & & Distance from water resources $>750 \mathrm{~m}$ & Not suitable & 1 \\
\hline \multirow{4}{*}{$\begin{array}{l}\text { Nature tourist } \\
\text { attractions }\end{array}$} & \multirow{4}{*}{-} & $\begin{array}{l}\text { Distance from nature tourist attractions } 0-250 \\
\mathrm{~m}\end{array}$ & High & 4 \\
\hline & & $\begin{array}{l}\text { Distance from nature tourist attractions } 250- \\
500 \mathrm{~m}\end{array}$ & Moderate & 3 \\
\hline & & $\begin{array}{l}\text { Distance from nature tourist attractions } 500- \\
750 \mathrm{~m}\end{array}$ & Marginal & 2 \\
\hline & & Distance from nature tourist attractions $>750 \mathrm{~m}$ & Not suitable & 1 \\
\hline
\end{tabular}

Source: Bunruamkaew and Murayama (2011), Liaghat et al., (2013), Dhami et al., (2014). Wu et al., (2015), Fernando \& Shariff (2017), Sadikin et al., (2017), modified

\section{Data Collection}

After the evaluation criteria had been determined, spatial data as seen in Table 2 were collected from online and offline searches. Also, the field survey was conducted on the landscape element (land cover) from the classification of Spot 6/7 images to obtain data on the landscape potential. Based on the spatial data, eight thematic maps were made (DEM, road network, existing tourism destination sites, land cover, forest area, settlement, river network, and distribution of tourism potential).

Table 2: List of data and their sources

\begin{tabular}{lcll}
\hline Data & Scale & \multicolumn{1}{c}{ Sources } & Year Acquired \\
\hline Digital Elevation Model (DEM) & $1: 25.000$ & Demnas (http://tides.big.go.id/ & $18^{\text {th }}$ of September \\
& & DEMNAS/index.html) & 2019 \\
Spot 6/7 Imagery (Land cover, & & LAPAN (National Space and & 2018 \\
$\begin{array}{l}\text { Road Network, River Network, } \\
\text { Waterbody, Settlement) }\end{array}$ & & Aviation Agency) \\
\hline Forest Area & & Ministry of Environment \& Forestry, \\
& & Indonesia \\
The Potential of Landscape & & Field Survey \\
\hline Boundary Map & $1: 25.000$ & $\begin{array}{l}\text { Public Work and Housing Agency, } \\
\text { Soppeng District, Indonesia }\end{array}$ \\
\hline
\end{tabular}




\section{Criteria Maps Generation}

Based on eight thematic maps that had been collected, eight criteria maps (Figure 3) were generated through spatial analysis and are as follows: slope map (3a) measured from DEM using surface analysis; accessibility maps based on proximity from the existing tourism destination site (3b) measured from the site's coordinates using buffering analysis; accessibility map based on distance from roads $(3 \mathrm{c})$ measured from the road network using buffering analysis; naturalness map based on land cover (3d) measured from the level of naturalness of land cover; naturalness map base on distance from the settlement (3e) measured from polygon settlements using buffering analysis; naturalness map based on the status of protected area (3f) measured from the level of preservation area; distance from water sources map (3g) measured from river networks using buffering analysis; distance from nature tourist attraction map (3h) measured from the coordinates of tourism potential using buffering analysis.

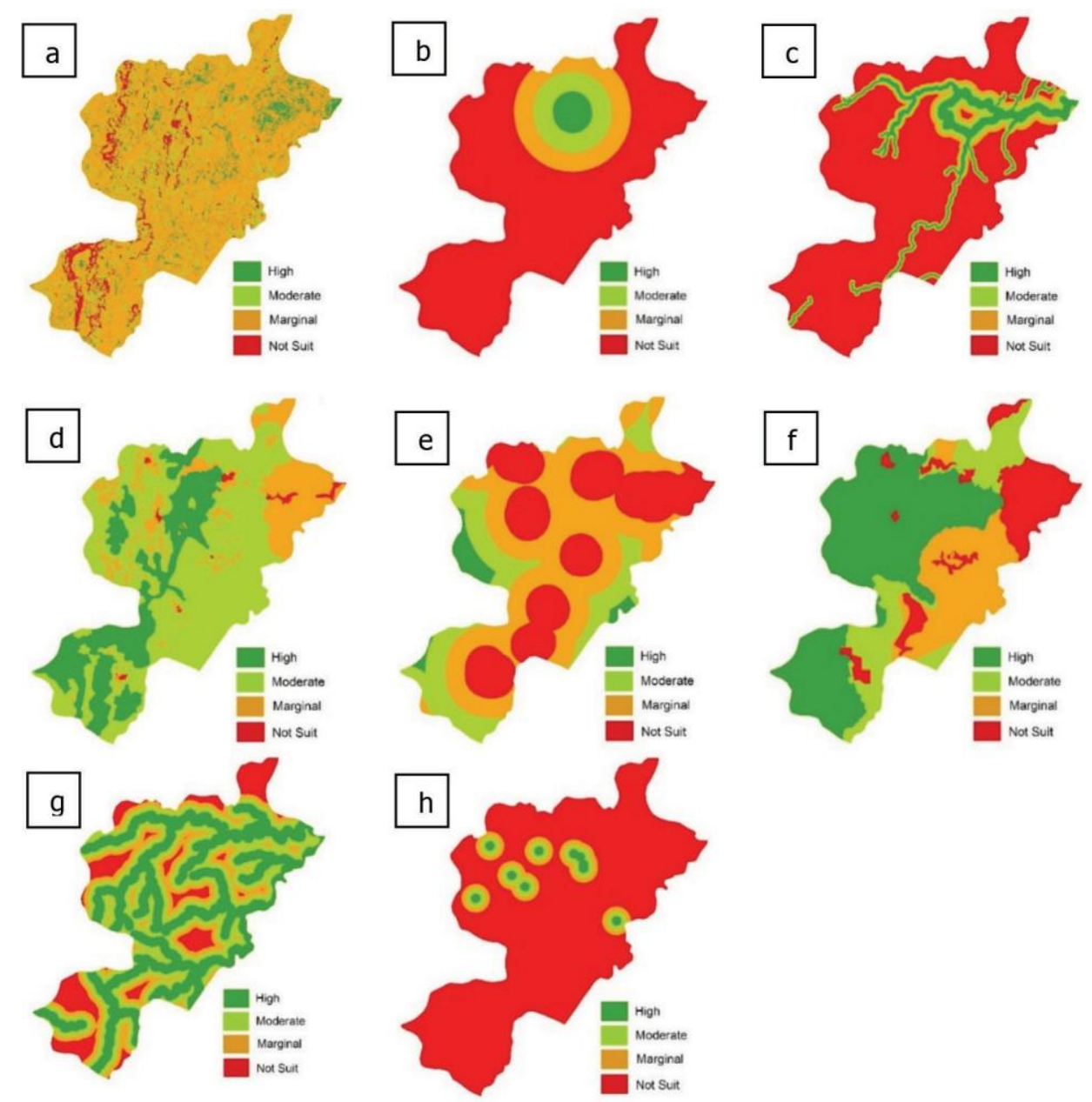

Figure 3: Eight Maps of Criteria for Ecotourism's Site Suitability Evaluation: Slope (a), Accessibility based on proximity from the existing tourism destination site (b), Accessibility based on distance from roads (c), Naturalness based on land cover (d), Naturalness based on distance from settlements (e), Naturalness based on preservation status (f), Distance from water resources (g), Distance from nature tourism attraction potential (h)

Source: Authors' analysis 


\section{Determining Weight Value for Each Criterion}

After obtaining eight criteria maps, each criterion was weighted by the AHP through an expert questionnaire. The questionnaire was designed with a relative comparison assessment system between criteria. The comparison scale used in the questionnaire is 1 to 5 , where scale 1 = equally important, scale 2 = slightly more important, scale $3=$ more important, scale $4=$ very important; and scale $5=$ absolutely more important (Wu et al., 2015).

Questionnaire data processing using AHP obtained an overall inconsistency value of 0.01 (the maximum allowed is 0.1 ) which means that the overall inconsistency value is still below the maximum value so that the weighting results can be accepted. The weight value of each criterion using the ideal model was presented in Table 3.

\section{Spatial Multi-criteria Decision Analysis}

Spatial Multi-criteria Decision Analysis is an integration of GIS and AHP. Eight maps of criteria resulted from GIS analysis (Figure 3) and the weight value of eight criteria resulted from AHP analysis (Tabel 3) are linearly combined using Equation 1 (Bunruamkaew \& Murayama, 2011).

$$
S i=\sum_{i=1}^{n}(W i x R i)
$$

Where "Si" is the total suitability score for each site unit (i.e. each raster cell in the map), " $n$ " is the number of criteria, "Wi" is the weight value of each criterion of "ith" (as seen in Table 3) and "Ri" is the score for each site unit of " $i$ th" criteria (as seen in Table 1). The total suitability score was classified into 4 suitability classes (High, Moderate, Marginal, Not Suitable) and their suitability scores were presented in the standardised format i.e. $1-1.75$ (Not Suitable), $>1.75-2.5$ (Marginally Suitable), > $2.5-3.25$ (Moderately Suitable), >3.25 - 4 (Highly Suitable).

\section{Data Synthesis}

Suitability map for ecotourism development was obtained through an overlay process of eight criteria maps using union analysis.

\section{Results and Discussion}

\section{The Characteristics of Landscape}

Landscape elements of Bulue Village were dominated by secondary forest $56.393 \%$ and primary forest $24.24 \%$ based on object-based image analysis from Spot 6/7 imagery acquired in 2018. Other elements were rainfed field $8.917 \%$, mixed plantation $4.393 \%$, rice field $2.767 \%$, shrub $2.312 \%$, settlement $0.976 \%$, and swamp $0.003 \%$.

The community of Bulue Village is divided into 9 settlements (Mario, Galungkalunge, Lejja, Datae, Gellenge, Kajuara, Poro, Lamatanruk, and Wawogalunge). They are an agricultural society. Meanwhile, the protected forest area which is upstream of the river that flows into Datae and

Table 3: Weight Value of Criteria using AHP

\begin{tabular}{llc}
\hline No & Criteria & Weight \\
\hline 1. & Slope & 0,049 \\
\hline 2. & Accessibility based on proximity from existing tourism destination sites & 0,127 \\
\hline 3. & Accessibility based on distance from roads & 0,114 \\
\hline 4. & Naturalness based on land cover & 0,150 \\
\hline 5. & Naturalness based on distance from settlements & 0,074 \\
\hline 6. & Naturalness based on preservation status & 0,156 \\
\hline 7. & Distance from water resources & 0,149 \\
\hline 8. & Distance from nature tourist attraction & 0,181 \\
\hline
\end{tabular}

Source: Authors' analysis 
Gellenge settlements has been degraded. The source of living in the community is dominated by farming. They need the extensification of farming for mixed plantation to increase their income. The extensification of farming has caused landscape fragmentation. According to Prasetyo (2017), landscape fragmentation will change a small portion of native habitat into a new habitat, which triggers the process of emigration and immigration of plant and animal species. While Wahid et al. (2015), based on research in the protected forest of Sinjai District, had found that the community encroached the forest because they did not know that the area is a protected forest area. It was caused by rare or unclear boundary signs of the protected forest area. To protect from further forest degradation, the forest extension should be done as preventive approaches.

The disturbance to protected forest areas has increased the level of turbidity, dissolved sediment, and nitrate content, especially in the rainy season. Disturbance in the form of illegal logging and the conversion of part of the forest area into mixed fields do not significantly affect the decline in river water quality. However gold mining, settlement, and agriculture activities in the form of rice fields caused a significant decline in river water quality (Supangat, 2013). Due to the total percentage of the land cover of the Bulue landscape in the form of mixed plantations, settlements, rice fields, and rainfed fields was $17 \%$. Also, there was a high fluctuation in river flows between rainy season and dry season. Thus, it can be said that land use activities in the Bulue landscape, more or less affect habitat changes in the upstream and water quality in the downstream, especially in the rainy season. Currently, the width of Lake Tempe has shrunk extensively due to massive sediment flow from the upstream eroded land in rainy seasons (Marjuki, 2016).

There were some nature-based tourism attractions (as seen in Table 4) which were dominated by aquatic-based attractions in line with the major function of the landscape as the upstream area of the Batu-Batu River which provides flows to Lake Tempe. Lejja Hot

Table 4: The Nature-based Tourism Attractions of Bulue Village, Soppeng District, Indonesia

\begin{tabular}{|c|c|c|}
\hline No & $\begin{array}{c}\text { Nature-based tourism } \\
\text { attractions }\end{array}$ & Descriptions \\
\hline 1 & Lejja Hot Springs & $\begin{array}{l}\text { Smell-free sulfur of hot spring water sources are used by visitors. It } \\
\text { has become a tourist destination for the relaxing soak activities. }\end{array}$ \\
\hline 2 & Anoa Sanctuary & $\begin{array}{l}\text { It was built as semi-natural cage in Lejja recreation park for preserving } \\
\text { the endemic Sulawesi animals. }\end{array}$ \\
\hline 3 & Lejja View & The natural scenery of the Bulue landscape is portrayed. \\
\hline 4 & Camping ground & $\begin{array}{l}\text { An attractive of natural scenery and potential space for the camping } \\
\text { area is available. }\end{array}$ \\
\hline 5 & Datae Hot Springs & $\begin{array}{l}\text { Warm water recreation has potential and is noted located near the } \\
\text { river flows, mixed between warm water and cold water. }\end{array}$ \\
\hline 6 & Menawoe Waterfall & $\begin{array}{l}\text { Waterfalls with a total height of } \pm 10 \mathrm{~m} \text { in a relatively remote area is } \\
\text { portrayed. }\end{array}$ \\
\hline 7 & Lapaserengi Waterfall & One-level waterfalls with a height of $\pm 5 \mathrm{~m}$ is located near Datae. \\
\hline 8 & Batumurue Waterfall & One-level waterfalls with a height of $\pm 15 \mathrm{~m}$ is located near Datae. \\
\hline 9 & Waepuange Waterfall & $\begin{array}{l}\text { One-level waterfalls with a height of } \pm 25 \mathrm{~m} \text { located in a remote area } \\
\text { is shown. }\end{array}$ \\
\hline 10 & Sarasa-tandre Waterfall & $\begin{array}{l}\text { The stratified waterfall with a total height of } \pm 15 \mathrm{~m} \text { is located near } \\
\text { Gellenge. }\end{array}$ \\
\hline
\end{tabular}

Source: Authors' analysis 
Springs, Lejja View, Anoa Sanctuary, camping ground, Datae Hot Springs, and Lapaserengi Waterfall were located in Lejja Recreation Park. Meanwhile, Menawoe Waterfall, Batumurue Waterfall, Waepuange Waterfall, and Sarasatandre Waterfall are located in Walanae Protected Forest.

Generally, accessibility to Lejja Hot Springs, Anoa Sanctuary, Lejja View, and camping ground is through a paved road. Accessibility to Datae Hot Springs, Menawoe Waterfall, Batumurue Waterfall, Waepuange Waterfall, Sarasa-tandre Waterfall, and Lapaserengi Waterfall is through secondary roads and trail roads. Lejja Hot Springs have become the leading tourist destination of Soppeng District, which is under the management of Soppeng Regional Owned Enterprise licensed by South Sulawesi Nature Resources Conservation Agency as the conservation area authority. Meanwhile, other potentialities have not been chosen nor utilised as tourist destination objects .

The visitors of Lejja Hot Springs are domestic tourists, mostly between the ages of 13 -25 years old. From 2015 to 2019, the number of tourists decreased steadily. According to South Sulawesi Nature Resources Conservation Agency (2020), there were 113,629 tourists ( 2015), 89,665 tourists (2016), 100,786 tourists (2017), 2018 (90,225 tourists), and 87,687 tourists (2019). In the holiday season, there is a surge in the number of tourists. In 2017, the peak of the visits occurred in July of with 31,401 tourists, while in 2018, the peak of the visits occurred in June, with as many as 22,240 tourists. The existence of Lejja Hot Springs certainly provide a market opportunity for the ecotourism development of other tourism attractions in Bulue. Nevertheless, the community interest in developing ecotourism is still low (Forestry Agency of South Sulawesi Province, 2018). That low interest can be caused by several factors such as minimum support and promotion from the government or stakeholders, lack of knowledge in managing tourism sites, and also because of poor infrastructure and accessibility to a remote location.
Besides the nature-based tourism attractions, the livelihood of Bulue people also could attract special travellers i.e. harvesting honey directly from the forest, and traditional palm sugar making. The activity of observing the process of taking honey in a tree, eating a beehive containing eggs and larvae mixed with honey could be included in a tour package. The livelihood of the Bulue people is mostly dependent on nature. The lack of electricity has encouraged the community to use river flows for micro-hydropower plants. Life dependence on nature has the potential to create strong bonds. Thus, it can be used as social capital to include the community in maintaining the preservation of natural resources.

The potential that has not been chosen nor utilised as tourist destination objects could be developed as new destinations through a participatory process. However, the community needs to be strengthened through the development of the ecotourism network which is a modification of Jaringan Ekowisata Desa (JED) developed in Bali. JED was formed to realise ecotourism programmes based on the community and the environment and as a form of commitment from several community groups who want to determine their future, culture, and environment (Saragih, Sendra, \& Mananda, 2015). Bali as a major tourist destination in Indonesia and its people have actively implemented Community-Based Ecotourism (CBE) as a reaction to mass tourism activities that not only bring economic growth but also lead to ecological and social costs. The CBE initiative began by forming Jaringan Ekowisata Desa (JED) in collaboration with NGOs to find a more sustainable approach to tourism through stronger ownership and minimisation of negative ecological impacts (Byczek, 2011).

\section{Site Suitability for Ecotourism Development}

According to the site suitability map (Figure 4), site suitability classes of Bulue Village were (1) Highly Suitable 1.33\%; (2) Moderately Suitable 16.95\%; (3) Marginally Suitable $73.21 \%$, and (4) Not Suitable $8.51 \%$ for ecotourism. 
Site units that were highly suitable for ecotourism development spread in four locations, (1) site within Lejja Recreation Park which contains Lejja Hot Springs, Anoa Sanctuary, camping ground, and Lejja View; (2) site within Lejja Recreation Park contains Datae Hot Springs; (3) site within Lejja Recreation Park contains Lapaserengi Waterfall; and (4) site within Walanae Protected Forest contains Batumurue Waterfall. Site units that were moderately suitable for ecotourism are scattered in several locations both within Lejja Recreation Park and Walanae Protected Forest that includes Menawoe, Waepuange, and Sarasa Tandre Waterfalls. Site units that were marginally suitable for ecotourism were mostly found in Walanae Protected Forest, a small portion in Lejja Recreation Park and cultivation areas. Site units that were not suitable for ecotourism were only found in Walanae Protected Forest and cultivation areas.
Other studies related to ecotourism suitability assessment in Indonesia resulted in the land suitable for ecotourism based on tourism object, land cover, zone type, biodiversity and slope (Sadikin et al., 2017) or the areas recommended for nature-based tourism planning based on high resources attraction and high accessibility (Rahayuningsih et al., 2016). While this study was done by analysis based on factors such as naturalness (land cover, distance from the settlement, preservation status), slope, water resources, accessibility (distance from roads, and proximity from existing tourism destination sites), and natural tourist attractions.

The highly and moderately class of site suitability map for ecotourism of Bulue Village could be used as an ecotourism zone of Bulue Village. For that, the integrated regional planning is needed among stakeholders such as Lejja Recreation Park, Walanae Protected Forest, and the Soppeng District Government.

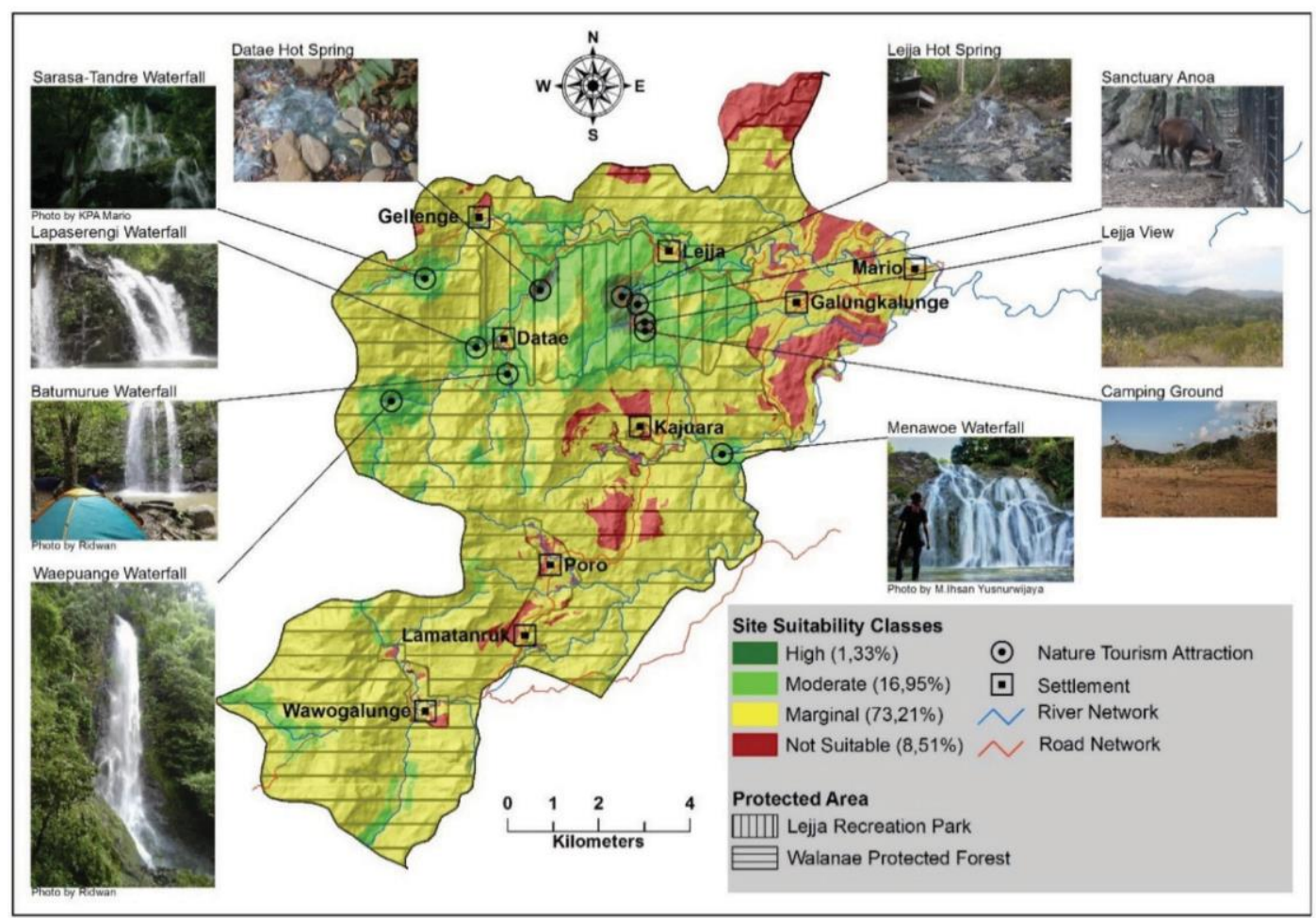

Figure 4: Site suitability map for ecotourism of Bulue Village, Soppeng District, Indonesia Source: Authors' analysis 
From the perspective of planning literature, integration is the natural part of a more holistic spatial planning (Straalen, 2012). Integration helps the stakeholders to understand each other, share interests, and might more easily seek cooperation in future planning projects. Also, the necessity of policy integration which will benefit effective planning projects.

To develop ecotourism based on evaluation and mapping of landscape not only depends on site suitability class for ecotourism development but also characteristics of the landscape such as environmental aspects (land cover/land use, water resources), livelihood and community interest, and tourism's potential (tourism attractions, infrastructure, and market opportunity). The nature-based tourism attraction potential and the livelihood of people who are closely related to nature is the driving factor of ecotourism development. Also, the market opportunity of tourism came from the visitors of Lejja Hot Springs. Besides, mostly $80 \%$ of the Bulue Village area was covered with primary and secondary forests with the function of protected areas that makes it suitable to be a conservation village. Conservation village is a conservation model approach that provides opportunities for people living around conservation areas to be actively involved in efforts to manage conservation areas (Nugroho \& Setyowati, 2014).

On the other hand, a high fluctuation in waterfall flow between rainy season and dry season due to forest degradation, the low interest of the community in developing ecotourism, and poor and remote access to some nature tourism attractions have become the resistance factors of ecotourism development. To weaken the resistance factors and strengthen the driving factors, then force field analysis could be used to obtain the strategic priority in developing ecotourism of Bulue Village.

\section{Conclusion}

Proper management of the landscape is important to ensure sustainable use. Ecotourism as part of a protected area's management strategy creates a symbiotic relationship by providing an alternative income for the local community and preserving the sustainability of the landscape. In the process of ecotourism development planning of the protected area, site suitability evaluation was an important step that accommodated the landscape characteristics such as environmental aspects, livelihood and community interest, and tourism's potential. Site suitability evaluation that employed spatial multicriteria decision analysis combined with descriptive analysis not only had resulted in the site suitability map for ecotourism but also had revealed the driving factors and resistance factors of ecotourism development. While other ecotourism suitability assessments only resulted in either the areas recommended for ecotourism or the land suitable for ecotourism.

As the landscape that has the major function as protected areas, Bulue Village in Soppeng District, Indonesia had (1) highly suitable $1.33 \%$; (2) moderately suitable $16.94 \%$; (3) marginally suitable $73.21 \%$, and (4) not suitable $8.51 \%$ for ecotourism development. Moreover, there were some nature tourism attractions potential (five waterfalls, two hot springs, one wildlife sanctuary, one nature scenery, and one camping ground), livelihood-based tourism attractions potential, and tourism market opportunities. However, there were also the resistance factors that need to be overcome in particular preventing further forest degradation, improving access to tourism attractions, and empowering the community.

The highly and moderately class of the site suitability map for ecotourism could be used as the ecotourism development zone of Bulue Village. The driving and resistance factors could be synchronized with the ecotourism development zone to determine the priority strategy of ecotourism development.

\section{Acknowledgements}

The authors would like to thank South Sulawesi Nature Resources Conservation Agency for its facilities while conducting this study. This study is part of a thesis which was submitted as partial 
fulfillment to meet requirements for the degree of Master at Hasanuddin University.

\section{References}

Bunruamkaew, K., \& Murayama, Y. (2011). Site Suitability Evaluation for Ecotourism Using GIS \& AHP : A Case Study of Surat Thani Province, Thailand. Procedia Social and Behavioral Sciences, 21, 269-278. https:// doi.org/10.1016/j.sbspro.2011.07.024

Byczek, C. (2011). Blessings for All ? Community-Based Ecotourism in Bali Between Global, National, and Local Interests - A Case Study. Austrian Journal of South-East Asian Studies, 4(1), 81-106.

Dhami, I., Deng, J., Burns, R. C., \& Pierskalla, C. (2014). Identifying and mapping forestbased ecotourism areas in West Virginia e Incorporating visitors , preferences. Tourism Management, 42, 165-176. https:// doi.org/10.1016/j.tourman.2013.11.007

Drumm, A., \& Moore, A. (2005). Ecotourism Development - A Manual for Conservation Planners and Managers Volume $l$ : An Introduction to Ecotourism Planning, Second Edition. (A. Singer, Ed.) (First edit, Vol. I). Arlington, Virginia, USA: The Nature Conservancy Worldwide Office, 4245 North Fairfax Drive, Arlington, VA 22203, USA.

Ecotourism.org. (2019). What Is Ecotourism? Retrieved from https://ecotourism.org/ what-is-ecotourism/

Fernando, S. L. J., \& Shariff, N. M. (2017). Site Suitability Analysis for Ecotourism Development at the Kirala Kele PartialNature-Based Wetland of Southern Sri Lanka. International Journal of Sciences: Basic and Applied Research, 32, 89-104.

Forestry Agency of South Sulawesi Province. (2018). Rencana Pengelolaan Hutan Jangka Panjang (RPHJP) KPHL Unit XII Walanae Periode 2019 - 2028. Makassar (INA): Dinas Kehutanan Provinsi Sulawesi Selatan.
Janic, M., \& Sestras, P. (2019). Identification and Evaluation of Landscape as a Precondition for Planning Revitalization and Development of Mediterranean Rural Settlements - Case Study : Mrkovi Village, Bay of Kotor, Montenegro. Sustainability, 11(2039), 1-15. https://doi.org/10.3390/ su11072039

Kiper, T. (2013). Role of Ecotourism in Sustainable Development. In Advances in Landscape Architecture (pp. 774-802). INTECH.

Liaghat, M., Shahabi, H., Rokni, B., \& Sattari, F. (2013). A Multi-Criteria Evaluation using the Analytic Hierarchy Process Technique to Analyze Coastal Tourism Sites. APCBEE Procedia, 5, 479-485. https://doi. org/10.1016/j.apcbee.2013.05.081

Marjuki, B. (2016). Pendangkalan Danau Tempe Sulawesi Selatan (1981 - 2015) dan Upaya Konservasi Sumber Daya Air. Jakarta (INA). Retrieved from https://setjen.pu.go. id/pusdatin/_uploads/artikel/27 Desember 2016 - Bramantyo Marjuki.pdf

Mobaraki, O., Abdollahzadeh, M., \& Kamelifar, Z. (2014). Site suitability evaluation for ecotourismusing GIS and AHP: Acase study of Isfahan Townships, Iran. Management Science Letters, 4, 1893-1898. https://doi. org/10.5267/j.msl.2014.6.038

Mohd, Z. H., \& Ujang, U. (2016). Integrating Multiple Criteria Evaluation and GIS In Ecotourism. In The International Archives of the Photogrammetry, Remote Sensing and Spatial Information Sciences (Vol. XLII, pp. 3-5). https://doi.org/10.5194/ isprs-archives-XLII-4-W1-351-2016

Nugroho, S. S., \& Setyowati, N. D. (2014). Model Pengembangan Desa Konservasi Berbasis Pendayagunaan Potensi Lokal Kawasan Lindung Lereng Gunung Wilis Kabupaten Madiun Jawa Timur. Sosial, 15(September), 54-62.

Prasetyo, L. B. (2017). Pendekatan Ekologi Lanskap untuk Konservasi Biodiversitas. 
Bogor (INA): Fakultas Kehutanan, Institut Pertanian Bogor.

Rahayuningsih, T., Muntasib, E. K. S. H., \& Budi, L. (2016). Nature Based Tourism Resources Assessment Using Geographic Information System (GIS): Case Study in Bogor. Procedia Environmental Sciences, 33, 365-375. https://doi.org/10.1016/j. proenv.2016.03.087

Sadikin, P. N., Arifin, H. S., Pramudya, B., \& Mulatsih, S. R. I. (2017). Carrying capacity to preserve biodiversity on ecotourism in Mount Rinjani National Park, Indonesia. Biodiversitas, 18(3), 978-989. https://doi. org/10.13057/biodiv/d180316

Saragih, W. R. J., Sendra, I. M., \& Mananda, I. G. S. (2015). Karakteristik dan Motivasi Wisatawan Ekowisata di Bali (Studi Kasus di Jaringan Ekowisata Desa). Jurnal IPTA, $3(1), 17-21$.

South Sulawesi Nature Resources Conservation Agency. (2020). Laporan Kinerja 2019 Balai Besar KSDA Sulawesi Selatan. Makassar (INA): Balai Besar KSDA Sulawesi Selatan.

Statistics of Soppeng Regency. (2018). Marioriawa Subdistrict in Figures 2018. Watansoppeng (INA): BPS Kabupaten Soppeng.
Stoddard, J. E., Pollard, C. E., \& Evans, M. R. (2012). The Triple Bottom Line: A Framework for Sustainable Tourism Development. International Journal of Hospitality and Tourism Administration, 13(3), 233-258. https://doi.org/10.1080/15 256480.2012.698173

Straalen, F. M. van. (2012). The Concept of Integration in Spatial Planning : An Exploration. In AESOP 26th Annual Congress (pp. 1-12).

Supangat, A. B. (2013). Effects of Disturbances of Protected Forest Area on River Water Quality: Case Study at Jambi Province. Indonesian Forest Rehabilitation Journal, 1, 75-89.

Wahid, A. M. Y., Bohari, N., \& Achmad. (2015). The Environmental Law Enforcement in Forestry Sector (Study on the Protected Forest in Sinjai Region, South Sulawesi). Hasanuddin Law Review, 1(1), 61-73.

Wu, W., Zhang, X., Yang, Z., Qin, W., Wang, F., \& Wang, C. (2015). Ecotourism Suitability and Zoning from the Tourist Perspective : a Nature Reserve Case Study, 24(6), 26832697. https://doi.org/10.15244/pjoes/59422 